\title{
Balancing corporate and social interests: Corporate governance theory and practice
}

\begin{abstract}
The claim is often made that corporate governance is an attempt to balance corporate interests with individual and societal interests. Lord Adrian Cadbury, who chaired the Cadbury Commission that produced the Cadbury Report on Corporate Governance in the UK, claims that the objective of corporate governance "is to align as nearly as possible the interests of individuals, corporations and society". This paper will test whether this claim can be substantiated on the theoretical and practice level. To test this claim on the theoretical level the concept of corporate governance will be analysed in order to determine whether the said balance is implied by the concept of corporate governance. In order to determine whether the claim find support in corporate governance practices around the world, six continental or regional reports on the relationship between business ethics and corporate governance, representative of the various regions of the world (Africa, Asia-Pacific region, Europe, Japan, Latin America and North America), will be analysed critically. On the basis of this conceptual and corporate governance practice analysis an assessment will be made of whether corporate governance is about "align[ing] as nearly as possible the interests of individuals, corporations and society".
\end{abstract}

Key words: Corporate governance, business ethics, shareholders, stakeholders, corporate law, agency theory, stakeholder theory, board of directors

\section{Introduction}

The claim is made by some that corporate governance is an attempt to balance corporate interests with societal and individual interests. Lord Adrian Cadbury, who chaired the Cadbury Commission that produced the Cadbury Report on Corporate Governance in the UK, claims that "corporate governance is concerned with holding the balance between economic and social goals and between individual and communal goals ... the aim is to align as nearly as possible the interests of individuals, corporations and society" (IoD 2002:5). The same sentiment was earlier echoed by a former CEO of General Electric, Ralph Cordiner, who said that corporations should be managed "in the best balanced interest of

Dr. G J (Deon) Rossouw is Professor and Head of the Philosophy Department at the University of Pretoria. He was the Founding President of the Business Ethics Network of Africa (BEN-Africa) and is the current President of the International Society of Business, Economics and Ethics (ISBEE). He is also the Director of the Centre for Business and Professional Ethics at the University of Pretoria. He is a member of the Sustainability Committee of the Third King Report on Corporate Governance for South Africa. shareholders, customers, employees, suppliers, and plant community cities" (in Monks and Minow, 2004:50). The Second King Report on Corporate Governance for South Africa makes a similar claim when it states that "the key challenge for good corporate citizenship is to seek an appropriate balance between enterprise (performance) and constraints (conformance), so taking into account the expectations of shareowners for reasonable capital growth and the responsibility concerning the interests of other stakeholders of the company" (IoD 2002:6; also see Fallon \& Treleaven 2006).

The purpose of this paper is to explore the claim that corporate governance can serve to balance individual, corporate and societal interests on two levels. Firstly the concept of corporate governance will be theoretically analysed to determine to what extent the balancing of the interests of the said parties is implied by the concept of 'corporate governance' itself. Secondly the claim will be measured against corporate governance practices on all six continents in order to ascertain the extent to which existing corporate governance practices reflect a balancing of individual, corporate and societal interests.

\section{Corporate governance: A theoretical exploration}

Corporate governance is a complex concept with many dimensions. To engage meaningfully with the concept the scope of corporate governance must be clarified. For the purpose of this paper especially three distinctions with regard to corporate governance are crucial. They are the distinctions between (a) the internal and external dimensions of corporate governance; (b) shareholder and stakeholder approaches to corporate governance; and (c) normative and descriptive definitions of corporate governance. Once these distinctions have been clarified the question of whether corporate governance conceptually implies a balancing of individual, corporate and societal interests can meaningfully be answered.

\section{- Internal and external corporate governance}

The distinction between internal and external corporate governance hinges on the question whether the locus of control for corporate governance is located inside or outside corporations (cf. Rossouw, Van der Watt \& Malan 2002). Conceptions of corporate governance that locate the responsibility for corporate governance inside the corporation (i.e., with the board and executive management) can be 
labelled as internal corporate governance. On this level governance refers to the way in which a company directs and controls its own affairs. A widely used definition of corporate governance on this level is the one that was introduced by the Cadbury Report on Corporate Governance in the UK which defined it as: "the system by which a company is directed and controlled" (Smerdon 1998:1). Thus the responsibility for corporate governance lies with the board of directors and executive management of a corporation and consists of two main functions: the direction and control of the company. The board of directors and executive management are firstly responsible for determining the strategic direction and hence the ultimate performance of the company (Reinecke 1996:11). Secondly, they are responsible for the control of the company. This is referred to as their conformance responsibility. This entails supervising management to ensure that they execute strategic decisions effectively as well as being accountable to shareowners, external authorities and in some instances, even to other non-share-owning stakeholders for the way in which the company is being run.

The locus of control for corporate governance can also be located external to corporations in which case it can be called external corporate governance. On this level corporate governance refers to both the legal and regulatory environment within which corporations function, as well as to the market for corporate control. The former consists of the control over companies through institutions like the state, the judiciary and stock exchanges. They exercise external control over companies in general and over securities transactions in particular by determining the network of laws, rules and regulations within which corporations have to operate (Coffee 1998:69, Romano 1998:144). The purpose of such external control over the operations of companies is not only to lay down ground rules for key role players in order to provide protection to shareholders and/or stakeholders in corporate action, but also to prevent the market as such from failing due to malpractices (Romano 1998:148).

The second aspect of external control over corporations is the control over companies exercised through the market. Important here is the possibility of mergers and acquisitions in order to gain control over companies that do not satisfy the expectations of markets (cf. Gedajlovic \& Shapiro, 1998:535-536). This market for corporate control is thus driven by the expectations of shareowners that the companies in which they invest should be managed efficiently and that optimal value should be achieved and sustained.
- Shareholder and stakeholder approaches to corporate governance

The distinction between shareholder and stakeholder approaches to corporate governance hinges on the question: For whose benefit should corporations be governed? When corporate governance is focused on the interests of shareholders only, internal or external corporate governance can be characterised as shareholder orientated. Since the commencement of the separation of ownership and control in corporations, the shareholder model of corporate governance increasingly became associated with agency theory. This theory holds that managers are the agents of shareholders (or owners) and in their capacity as agents, are obligated to act in the best financial interest of the shareholders of the corporation (cf. Monks \& Minow 2004:111). An example of a definition of shareholder-orientated corporate governance is Shleifer and Vishny's definition of corporate governance. They describe corporate governance as "the ways in which suppliers of finance to corporations assure themselves of getting a return on their investment" (1997:737).

Approaches to corporate governance that do not merely focus on the interests of shareholders, but also on the interests of other stakeholders, can be labelled as stakeholder-orientated models of corporate governance. Such stakeholder models are premised upon stakeholder theory and conceive the corporation as a social institution (cf. Evan \& Friedman 1993:82; Wieland 2006:164) where the interest of various stakeholder groups should be protected and enhanced (cf. Donaldson \& Preston, 1995: $67 \&$ 11). Corporate governance is, accordingly, defined as a system that ensures that the board and management of corporations strike a balance between the interests of their various stakeholders. Collier and Roberts state that when the corporation is conceived of as a social institution, the purpose of corporate governance is "aligning and balancing a wide variety of potentially competitive interests within the corporation" (2001:67). A similarly stakeholderorientated notion of corporate governance is evident in the second King Report on Corporate Governance for South Africa when it states that the "inclusive approach [to corporate governance] requires that [...] the relationship between the company and its stakeholders should be mutually beneficial" (IoD 2002:6).

- Descriptive and normative corporate governance Definitions of corporate governance can be either descriptive or normative (prescriptive). Descriptive definitions of corporate governance provide an account of practices and ideas that are widely associated with corporate governance without making any value judgement about it. An example 
of a descriptive definition of internal corporate governance is the one by Sir Adrian Cadbury (and quoted above): "the system by which a company is directed and controlled" (Smerdon 1998:1). A wider descriptive definition that includes both internal and external corporate governance is Wieland's definition that defines corporate governance "as leadership, management and control of a firm by formal and informal, public and private rules" (2005:76).

Normative definitions of corporate governance venture beyond a mere description of practices and ideas associated with corporate governance and pose a specific standard that should be attained in corporate governance. Normative definitions of corporate governance are consequently related to the notion of 'good corporate governance'. An example of a normative definition would be the one quoted in the introduction to this paper, which defines corporate governance as being concerned "with holding the balance between economic \& social goals and between individual \& communal goals" (IoD, 2002:5). This definition is clearly focused on internal corporate governance only. Following the same line of reasoning this normative definition can be extended to include the external corporate governance dimension. This implies that corporate governance can be normatively defined as the external and internal system by which corporations are controlled in order to ensure a balance between individual, corporate and societal interests.

The above normative definition of both the internal and external dimension of corporate governance will become the focus in the remainder of the paper. The question is whether this specific normative conception of corporate governance finds support in corporate governance theory and practice. Before I turn to this question, three comments on the above normative definition are necessary: (1) this is only one example of a normative definition of corporate governance, and by no means the only one; (2) the fact that the above normative definition is closely aligned to the stakeholder approach to corporate governance does not imply that normative definitions only apply to stakeholder approaches and not to shareholder approaches to corporate governance as well; and (3) a clear distinction should be drawn between normative definitions of corporate governance and normative justifications of shareholder and stakeholder approaches to internal and external corporate governance.

\section{- Balance on the theoretical level?}

The very nature of normative definitions is that they discriminate between various forms of the phenomenon that they are referring to. In the case of corporate governance, normative definitions like the ones mentioned above would find some forms of corporate governance inadequate and thus not able to fulfil the normative standard set by the definition. The crucial criterion that internal or external corporate governance systems need to measure up to, in order to pass the above normative definition test, is that they should succeed in balancing individual, corporate and societal interests.

The nature of all corporate governance systems, whether internal or external, is that they intend to balance interests. The above definition of the shareholder approach to corporate governance by Shleifer and Vishny emphasises the balance between shareholders and the company, while the above stakeholder-orientated corporate governance definition of Collier and Roberts accentuates the balance amongst a variety of stakeholders of the corporation. It is clear that the issue of balance features in both shareholder and stakeholder models of corporate governance.

The fact that both shareholder and stakeholder approaches to corporate governance emphasises the issue of balance, however does not mean that both approaches pass the test implied by the normative definition of corporate governance that is used in this paper. The balance that is required is a balance between individual, corporate and societal interests. Shareholder models of corporate governance are geared towards ensuring that the interests of shareholders are balanced with those of the corporation, and more specifically with those of executive managers. The shareholder model of corporate governance is a response to the agency problem that developed because of the separation of ownership and control in the modern corporation. In order to prevent the abuse of managerial discretion various kinds of governance measures were introduced to ensure that managerial and shareholder interests were aligned or balanced (cf. Monks \& Minow, 2004:115). While the interests of some individuals, namely shareholders and managers, are balanced in the shareholder model of corporate governance, the same cannot be said of either individuals (such as employees, suppliers, customers), or societal interests. This does not mean that the interests of non-shareholding stakeholders would necessarily be neglected in shareowner models of corporate governance. It may serve the interest of both shareholders and managers to take the interests of other groups of stakeholders into consideration, but such consideration will be motivated by expedience, not by an ethical commitment to the interests of such stakeholders. The interests of stakeholders are thus only considered out of strategic (or instrumental) considerations, and not because they carry any normative weight (cf. Donaldson \& Preston, 1995:71; Goodpaster 1993:211).

Stakeholder models of corporate governance would better succeed in meeting the standard set by 
the normative definition of corporate governance used in this paper. What distinguishes stakeholder models from shareholder models of corporate governance is exactly the focus of the former on obligations of corporations to not only the interests of shareholders, but also to those of other stakeholders, including the society. This being the case, stakeholder models of corporate governance, whether on the internal or external level, have a greater potential of balancing individual, corporate and societal interests.

Purely on a conceptual level it is clear that corporate governance does not necessarily imply a balance of individual, corporate and societal interests, although some approaches to corporate governance do have the potential to achieve such a balance. In the second part of the paper, the question will now turn to the extent to which the said balance of individual, corporate and societal interest are achieved in various corporate governance regimes around the world.

\section{Corporate governance: A global assessment of practice}

To attend to the second objective of the paper, i.e. a global exploration of whether corporate governance practice succeeds in balancing individual, corporate and societal interests, an analysis of corporate governance practices around the world will be done. This analysis will be primarily based on six continental or regional reports on Business Ethics and Corporate Governance that were commissioned by the International Society of Business, Economics, and Ethics (ISBEE) and presented at the Third ISBEE World Congress in Melbourne in 2004. In these reports researchers from Africa, the AsiaPacific region, Europe, Japan, Latin America and North America reported on the relation between business ethics and corporate governance in their respective regions. Subsequent to their initial presentation at the said event, these six reports have been published in Business and Society (volume 44, numbers 1 and 2 of 2005) and revised and updated versions thereof have also been included in the book, Global Perspectives on the Ethics of Corporate Governance (Rossouw \& Sison, 2006). As all of the mentioned reports deal with the status and role of shareholders and other stakeholders in their respective regions, it provides a useful basis for determining to what extent attempts are made in the respective regions to balance individual, corporate and societal interests. In the case of each of the regions, the relationships that were found to exist between corporations and their stakeholders will first be described and thereafter discussed in the same sequence as mentioned above.

\section{- Africa}

Findings: In the African report, Rossouw analysed the 10 national corporate governance codes that have been developed by 2004 in Africa, viz. in Ghana, Kenya, Malawi, Mauritius, Nigeria, South Africa, Tanzania, Uganda, Zimbabwe and Zambia (Rossouw 2005:97). All of these national corporate governance codes have been developed on the initiative of the private sector, stock exchanges and/or professional associations (such as associations of accountants, auditors or lawyers). These codes are characterised by their emphasis on principles rather than rules as well as by their self-regulatory nature. The selfregulatory nature of these reports can be seen as a direct consequence of the poorly developed external corporate governance regimes and/or poor execution of existing laws and regulations that are supposed to govern corporate behaviour on the African continent. In the absence of strong and well-developed external corporate governance regimes, self-regulation on the internal corporate governance level seems the most viable option to ensure corporate control.

A strong convergence can be detected across the various national corporate governance codes in Africa. All reports, but one, opt for a stakeholder model of corporate governance in which not only accountability towards shareholders is recognised, but corporate social responsibility towards a variety of stakeholders and local communities is emphasised. The only exception amongst the African reports is the Nigerian corporate governance code that opts for a shareholder corporate governance model in which only an obligation towards shareholders is recognised.

TABLE 1:

INTERNAL/EXTERNAL GOVERNANCE AND STAKEHOLDER/ SHAREHOLDER MODELS

\begin{tabular}{|l|l|l|}
\hline & \multicolumn{1}{|c|}{$\begin{array}{c}\text { Internal } \\
\text { Corporate Governance }\end{array}$} & $\begin{array}{c}\text { External } \\
\text { Corporate Governance }\end{array}$ \\
\hline $\begin{array}{l}\text { Stakeholder } \\
\text { Model of } \\
\text { Gorporate }\end{array}$ & $\begin{array}{l}\text { Ghana } \\
\text { Kenya } \\
\text { Malawi } \\
\text { Mauritius } \\
\text { South Africa } \\
\text { Tanzania } \\
\text { Uganda } \\
\text { Zimbabwe } \\
\text { Zambia }\end{array}$ & $\begin{array}{l}\text { Poorly developed } \\
\text { systems of external } \\
\text { corporate governance } \\
\text { that leaves both } \\
\text { shareholders and } \\
\text { stakeholders vulnerable } \\
\text { (with the exception of } \\
\text { South Africa) }\end{array}$ \\
$\begin{array}{l}\text { Shareholder } \\
\text { Model of } \\
\text { Corporate } \\
\text { Governance }\end{array}$ & Nigeria & \\
\hline
\end{tabular}

Discussion: The dominant position taken on the African continent favours a balancing of corporate, societal and individual interests. This mainly applies to the internal corporate governance level, as Rossouw indicated in his African report that external corporate 
governance regimes are in general poorly developed or enforced. The strong convergence around a stakeholder approach to corporate governance can probably be attributed to a combination of factors. They include: African values that emphasise mutuality and belonging; a legacy of post-colonial African socialism that emphasises the interest of society; and a pragmatic recognition that sustainability depends on co-operation between all stakeholders in the African context, where more often than not, there is a lack of well developed national infra-structure as well as proper formal external corporate governance regimes.

\section{- Asia-Pacific}

Findings: In contrast to the African continent the Asia-Pacific region displays substantial divergence with regard to corporate governance practices. Kimber and Lipton, who compiled the Asia-Pacific report, indicate that they have selected four countries in the Asia-Pacific region not because they are representative of the region, "but because in themselves they are representative of the diversity that may be found in the region" (2005:179). The four countries are Australia, China, India and Singapore.

Kimber and Lipton distinguish three models of corporate governance in the Asia-Pacific region, viz. the contractarian model, the communitarian model and a hybrid model between the former two models. In the contractarian model the corporation is perceived as a nexus of contracts negotiated by self-interested shareholders, where control over the corporation is exercised through voluntary contracting and a market for corporate control (mergers and acquisitions). There is, however, no doubt that shareholder interests are dominant and are protected by both the external and internal corporate governance systems. Both Australia and Singapore are characterised as exponents of the contractarian model. The major difference between them is that ownership is more widely dispersed in Australia, while it is more concentrated in family ownership in Singapore. Since the corporate governance system favours the protection of shareholder interest, minority shareholders enjoy better protection in Australia with its widely dispersed ownership than in Singapore where dominant family ownership affords minority shareholders less protection. Other stakeholders and local communities also enjoy protection through the external corporate governance system of laws and government agencies in both Australia and Singapore. Differences in the protection of the interests of non-shareholding stakeholders between the two countries can be related to differences in levels of activism by civil society and stakeholder interest groups. Labour unions, consumer groups and NGOs are more active in Australia than in Singapore where the activities of such groups are more strictly controlled by government.
The second model of corporate governance that Kimber and Lipton identified in the Asia-Pacific region is the communitarian model (2005: 183). This model portrays the corporation as a separate entity that can both be beneficial and harmful to society. Consequently, there is a need to protect society and stakeholders through laws and regulations against the possible harmful effects of the corporation. China can be considered an exponent of the communitarian model since restrictions are imposed on large nonstate shareholders in order to prevent them from harming the interests of the state, stakeholders and society. In internal corporate governance the role of directors as good stewards and virtuous leaders, who have to take care of a wide spectrum of interests entrusted to them, is emphasised. The fact that the state is often the dominant shareholder, in combination with a tradition of strong dependency of stakeholders on the state, undermines the ability of harmed minority shareholders or other stakeholders to challenge the state.

India represents a hybrid model with elements of both the contractarian and the communitarian models. The Indian perception of the corporation is one of a community of interests where specifically the interests of the shareowners, managers and employees enjoy priority. Since the government is often the dominant or controlling shareholder, and the legal protection of shareholders is weak, the interests of minority shareholders are in jeopardy. The recognition of the importance of employees in the corporation, coupled with a tradition of volunteer social action on behalf of aggrieved parties (e.g. local communities, religious organisations or consumer groups) means that some balance between individual, corporate and societal interests is maintained in the internal corporate governance system. Like China, there is also a strong reliance on the role of directors as stewards of a variety of entrusted stakeholder interests.

Discussion: Kimber and Lipton's Asia-Pacific report shows a mixed and complex picture with regard to the balancing of individual, corporate and societal interests in that region. In both Australia and Singapore the internal and external corporate governance regulatory regime prioritise the protection of shareholders, and in the case of Australia an active market for corporate control further augments it. Although stakeholders' interests do enjoy some protection by law, the dominant protection is afforded to shareowners in both the external and internal corporate governance regime.

In China, however, there is an attempt to balance the interests of corporations with those of society and the state. This balance is mainly achieved through the laws and regulations of the external corporate governance system. Given the dominance of the state 
in Chinese society and economy, the balance is under constant threat of being skewed in favour of the state. The internal system of governance that emphasises the role of directors as good stewards and virtuous leaders is unlikely to be an effective counter-force to such domination by the state. Consequently the internal and external system of corporate governance in China can at best be characterised as mildly stakeholder orientated.

Of the four countries surveyed in the Asia-Pacific region, India seems to be the country that comes closest to achieving some balance between corporate, societal and individual interests. On the one hand, the external corporate governance system does not strongly favour the interests of shareholders, while, on the other hand, the internal corporate governance system seeks to balance shareholder, managerial and employee interests. Given the cultural orientation towards the protection of community and religious and minority interests, the corporate governance regime can be classified as stakeholder-orientated.

\section{- Europe}

Findings: Internal and external corporate governance regimes in Europe display a rich diversity. In his report on the corporate governance practices of 22 European countries, Wieland identified two broad perspectives on corporate governance, viz. the shareholder value perspective and the stakeholder value perspective. The shareholder perspective is closely associated with agency theory and therefore Wieland refers to the corporate governance model related to this perspective as the "maximization model" (2005:82). Within the stakeholder value perspective, two more models of corporate governance can be discerned: the "economising model" (2005:82) that focuses on economising transactions to the benefit of all transacting partners; and the "cooperation model" (2005:82) that emphasises interaction between owners of various internal and external resources that are required to create a competitive advantage for all stakeholders of the organisation.

The corporate governance practices of Europe are evenly spread between these three models of corporate governance, with seven countries (Switzerland, Czech Republic, Portugal, Sweden, Finland, Great Britain and Ireland) falling in the maximization model, eight countries (Austria, Belgium, Germany, France, Italy, Hungary, Russia and Turkey) in the economising model and seven countries (Denmark, Netherlands, Spain, Lithuania, Poland, Romania, Slovakia) in the co-operation model (as illustrated in the table below). However, Wieland notes that there are clear examples of "reciprocal learning processes" that can be detected between the more stakeholder and more shareholder orientated approaches to corporate governance, but that such learning "does not necessarily need to end up in the inadequate and not very fruitful reductionism of agency theory" (2005:88).

TABLE 2:

SHAREHOLDER/STAKEHOLDER PERSPECTIVES ACROSS COUNTRIES (ADAPTED FROM WIELAND, 2005: 83)

\begin{tabular}{|l|l|l|l|}
\hline & Shareholder perspective & \multicolumn{2}{|c|}{ Stakeholder perspective } \\
\hline Model & Maximization model & $\begin{array}{l}\text { Economizing } \\
\text { model }\end{array}$ & $\begin{array}{l}\text { Cooperation } \\
\text { model }\end{array}$ \\
\hline Countries & Switzerland & Austria & Denmark \\
& Czech Republic & Belgium & Netherlands \\
& Portugal & Germany & Spain \\
& Sweden & France & Lithuania \\
& Finland & Italy & Poland \\
& Great Britain & Hungary & Romania \\
& Ireland & Russia & Slovakia \\
& & Turkey & \\
\hline
\end{tabular}

Discussion: From the above analysis and categorisation it is clear that the majority of European countries (15 out of the 22 countries included in the survey) fall into either the economising or co-operation models of corporate governance. Both these models are associated with a stakeholder-orientation to corporate governance. It is thus safe to conclude that in these countries some form of balance between individual, corporate and societal interests are being sought in both the internal corporate governance regimes as well as the external control of corporations through regulations and the market. In contrast to shareholder orientated models of corporate governance that emphasize the protection of shareholders and control of management, the stakeholder models of corporate governance in Europe not only mention the rights of shareholders, but also place emphasis on ethical standards, communication and dialogue with a range of stakeholders as well as on social and environmental responsibility (cf. Wieland, 2005: 86). These latter kinds of measures indicate a distinct leaning towards balancing shareholder interests with those of the corporation, society and various groups of stakeholders. The remaining seven countries (included in the survey) follow a shareholder-orientation in which the balancing of individual, corporate and societal interests is unlikely to be a priority.

\section{- Japan}

Findings: In his report on Japan, Demise (2005) indicates that the major stakeholders in Japan used to be bankers and employees. In recent years the role of banks has declined, while the role of institutional investors is increasing. Employees remain an important stakeholder group, not only because the majority on boards of directors are executive managers, but also because non-executive directors often come from the ranks of former employees. Despite the fact that employees are considered an important stakeholder 
group, their interests are being taken care of in a paternalistic manner. Demise (2005:216) reports that karoshi (death from overwork) and harassment of workers remain a problem, and that workers are unlikely to protest and resist such practices. There are indications that the spectrum of stakeholders, whose interest are being taken care of, is expanding, since recent corporate governance reforms have placed greater emphasis on corporate social responsibility and communication with stakeholders.

Discussion: Although the maximisation of the interests of shareholders (and increasingly the interests of institutional investors) has been and remains a priority for boards of directors, there is sufficient evidence that employees' interests also play a significant role, not only in board decisions, but also in board compilation. Recent corporate governance reforms have also brought wider social interests and stakeholder communication into play. Thus it can be concluded that the Japanese corporate governance system moves beyond a pure shareholder model towards a stakeholder-orientation to corporate governance that attempts to balance a variety of stakeholder interests.

\section{- Latin America}

Findings: In their report that covers seven Latin American countries (Argentina, Brazil, Chile, Colombia, Mexico, Peru and Venezuela) Bedicks and Arruda demonstrate that a strong convergence exists between the corporate governance practices of Latin American countries. There are regular interactions between these countries on issues of corporate governance through forums such as the Latin American Institute of Corporate Governance and the Latin America Corporate Governance Roundtables (Bedicks \& Arruda, 2005: 220).

The dominant corporate governance scenario in Latin America is one where external corporate governance systems are poorly developed and executed and where concentrated ownership by influential families or the state prevails. Recent law reforms have contributed toward institutional investors having more influence and voice in matters of corporate governance. The interests of dominant shareholders enjoy protection by both the external and internal corporate governance system, while the interests of minority shareholders are neglected. The corporate governance system in Latin America thus seems strongly premised on shareholder value maximization and displays the typical traits of an agency theory perception of corporations. This perception is confirmed by the 2003 IBGC (Instituto Brasileiro de Governança Corporativa) survey in Brazil that found that Boards of Directors tend to focus on issues related to shareholders and capital, while stakeholder issues receive little attention. Ryan, in her report on corporate governance practices in Mexico, comes to a similar conclusion about both the external and internal corporate governance system in that country (2005:51).

There are indications that at least on the internal corporate governance level the lack of protection of stakeholders other than dominant shareholders is receiving attention. The Latin America Corporate Governance Roundtable produced a report on corporate governance in Latin America in 2003, which became known as the OECD White Paper on Corporate Governance in Latin America. The recommendations made in that report not only support the protection of minority shareholders, but also place more emphasis on the protection of the interests of employees and customers, as well as on the responsibility of business towards job creation and towards society in general (Bedicks \& Arruda 2005:222).

Discussion: It is clear that traditionally both the external and internal corporate governance systems almost exclusively favour dominant shareholder interests in Latin America. Thus it can hardly be claimed that there is an intention to find a balance between individual, corporate and societal interest. However, there does seem to be a departure from this almost exclusive focus on the interests of dominant shareholders in the making, at least on the level of internal corporate governance: not only are there indications that minority shareholders are starting to enjoy more protection, but also other nonshareholding stakeholders, like employees, customers and the society are receiving some attention.

\section{- North America}

Findings: In her report on corporate governance practices in North America, Ryan (2005) classifies the Canadian corporate governance system as a mixture between a stakeholder model and a shareholder model, while the USA is presented as a quintessential exponent of the latter model.

The Canadian external corporate governance system is characterised by a good and efficient judiciary system, but with corporate governance control decentralised to provinces. There is an ongoing tussle between provinces on whether they should follow the rule-based approach of their neighbour to the South, or whether they should stick to a more principle-based approach that relies on the integrity of directors and managers. Shareholding in companies is not as widely dispersed as in the USA and both concentrated and family controlled ownership is evident. This concentration of ownership makes the lack of protection for minority shareholders one of the most pressing issues in Canadian external corporate governance (Ryan 2005:59). 
On the level of internal corporate governance, boards of directors are not exclusively shareholder-orientated, and stakeholder issues do feature on the board agenda, although only a low percentage of boards (16\%) indicated in a 2005 survey that they do engage with stakeholders of the corporation (Ryan 2005:66). The stakeholder-orientation of boards seems to reflect the sentiment found amongst both shareholders and other stakeholders in two other surveys. In the one survey, $74 \%$ of respondents indicated that companies should not merely focus on profits, but also attend to their impact on employees, local communities and the country at large. In the other survey, 83\% of respondents agreed that corporations need to move beyond their traditional economic role (Ryan 2005:66).

The USA, according to Ryan, represents a "quintessential outsider system" (2005:55) characterised by dispersed ownership with increasing levels of institutional holdings, primacy of shareholders, protection of minority shareholders and strong capital markets (Ryan 2005:42). The external corporate governance system provides investor friendly procedural devices to shareholders, and courts under a common law system do not shy away from interpreting concepts like the fairness and fiduciary duties of directors.

With this strong emphasis on shareholders, stakeholders are treated instrumentally and their interests are only attended to as a means to maximize shareholder value. Since a survey conducted by Hillman and Klein (cf. Ryan 2005:59) found that instrumental stakeholder management of employees and customers has a positive financial impact, while stakeholder management in the case of the community, diversity and the natural environment has a negative financial impact, it is to be expected that the interests of the latter stakeholder groups are likely to be neglected. Non-shareholding stakeholders have little influence on the level of internal corporate governance and according to Ryan this state of affairs is likely to be condoned by the populace given the widely dispersed ownership of companies (2005:58).

Discussion: From the above findings it is clear that the Canadian system of external and internal corporate governance can be regarded as one that seeks to find some balance between the interests of dominant shareholders and those of other stakeholders of the firm. In this quest corporations are supported by the populace who favours an approach that would take corporations beyond a narrow focus on shareholder interests and financial performance, as well as by the state who favours strong social programmes. In the USA, to the contrary, the interests of all shareholders enjoy protection, while the interests of other stakeholders only enjoy instrumental status for the sake of shareholder value maximization. Non- shareholding stakeholders' interests are thus only likely to be attended to if there are indications that attention to their interests will advance the interests of shareholders. The USA thus lacks a normative stakeholder orientation that respects the interests of stakeholders regardless of their strategic importance for corporations. This strong shareholder model of corporate governance seemingly enjoys the support of both the state and the populace at large.

\section{Corporate governance as a balancing act}

I will conclude this section on the assessment of global corporate governance practices in terms of their ability to balance corporate, societal and individual interests, against the backdrop of the debate on whether there is a global corporate governance convergence in the making. The reason for the assessment against this specific backdrop is to determine to what extent the findings of this paper offer support for, or deviate from the expectation that we are witnessing a global convergence of corporate governance regimes around the world. Obviously, given the focus of this paper, this will not be a comprehensive assessment of all aspects of corporate governance regimes, but will be focussed on the question whether there is a convergence towards shareholder focussed corporate governance regimes or whether the convergence is directed towards stakeholder focussed corporate governance regimes.

In comparative corporate governance studies prominent theorists of corporate governance differ on whether we are witnessing a global convergence towards shareholder focussed corporate governance regimes. In their article with the provocative title, The End of History of Corporate Law, Hansmann and Kraakman claim that there is sufficient evidence that at least on the level of external regulatory corporate governance the world is converging on what they call a "shareholder-centered ideology of corporate law" (2001:439). This sentiment is shared by Reed (2002:243), Garrett (2004:148) and to some extent also by Coffee (1999:707). Other scholars, however, are less optimistic about the inevitability of such a convergence. La Porta et al., (1999:512-513 \& 2000:23-24) and Nestor and Thompson (2000:23) caution against too optimistic expectations of convergence and identify factors that might constrain a speedy convergence. Branson (2001) is particularly dismissive of the idea of a global convergence in corporate practice. He rejects both the need for a 'one size fits all' approach and argues that advocates of convergence base their ideas of convergence on a small and unrepresentative sample of countries. Furthermore he believes that significant cultural differences between nations and regions make the idea of convergence not only unlikely, but also unwanted (cf. Branson 2001:324-327). Equally pessimistic about the prospect of convergence are Bebchuk and Roe (1999) who caution that there 
are a variety of factors that are resisting - and are likely to continue resisting - a convergence to shareholder focussed corporate governance regimes. Amongst these factors that Bebchuk and Roe have identified count initial ownership structures and corporate rules in a country or region (1999:137) as well as cultural values and political ideologies (1999:168-169).

The findings of the global survey on the ethics of corporate governance that was discussed in the previous section, lend support to those who caution against too much optimism for the idea of a global convergence towards a shareholder focussed corporate governance regime. The findings of the survey is summarised in table 3 below.

TABLE 3:

SHAREHOLDER, STAKEHOLDER AND COMBINED PERSPECTIVES ACROSS COUNTRIES

\begin{tabular}{|c|c|c|}
\hline $\begin{array}{l}\text { Shareholder } \\
\text { Perspective }\end{array}$ & $\begin{array}{c}\text { Combination } \\
\text { of Shareholder } \\
\text { and Stakeholder } \\
\text { perspective }\end{array}$ & $\begin{array}{l}\text { Stakeholder } \\
\text { Perspective }\end{array}$ \\
\hline $\begin{array}{l}\text { Argentina } \\
\text { Australia } \\
\text { Brazil } \\
\text { Chile } \\
\text { Colombia } \\
\text { Czech Republic } \\
\text { Finland } \\
\text { Great Britain } \\
\text { Ireland } \\
\text { Mexico } \\
\text { Nigeria } \\
\text { Peru } \\
\text { Portugal } \\
\text { Singapore } \\
\text { Sweden } \\
\text { Switzerland } \\
\text { USA } \\
\text { Venezuela }\end{array}$ & Canada & $\begin{array}{l}\text { Austria } \\
\text { Belgium } \\
\text { China } \\
\text { Denmark } \\
\text { France } \\
\text { Germany } \\
\text { Ghana } \\
\text { Hungary } \\
\text { India } \\
\text { Italy } \\
\text { Kenya } \\
\text { Lithuania } \\
\text { Malawi } \\
\text { Mauritius } \\
\text { Netherlands } \\
\text { Poland } \\
\text { Romania } \\
\text { Russia } \\
\text { Slovakia } \\
\text { South Africa } \\
\text { Spain } \\
\text { Tanzania } \\
\text { Turkey } \\
\text { Uganda } \\
\text { Zambia } \\
\text { Zimbabwe }\end{array}$ \\
\hline
\end{tabular}

From the survey results it is clear that there is a good mix of shareholder and stakeholder corporate governance regimes to be found in the various countries of the world included in the survey. Latin America is the only region where a shareholder-orientation to corporate governance dominates - at least on the external regulatory corporate governance level. In North America the USA also has a similar orientation, but Canada deviates from the US approach by following an approach that is a hybrid position between a shareholder and stakeholder approach. Only about a third (seven countries) of the 22 countries included in the European survey have shareholderorientated regimes, with the vast majority (15 out of 22 ) displaying a stakeholder-orientation. Also the majority of African countries (9 out of 10) whose national corporate governance codes were surveyed showed a stakeholderorientation. The only country on the African continent that has a strong shareholder-orientation is Nigeria. In the Asia-Pacific region the four countries included in the survey differ considerably in terms of their shareholder or stakeholder-orientation. While Australia and Singapore stand firmly in the shareholder tradition, China displays a mild stakeholder-orientation, while India's approach to corporate governance can be classified as a stakeholderorientation. Finally, Japan also has more of stakeholderorientation.

It is also evident that even in those regions and countries where there is a shareholder-orientation on the external corporate governance level, there also appears to be a movement on the internal corporate governance level towards a more stakeholder-orientation. This is particularly true in the case of Latin America, with its traditional strong leaning towards a shareholder orientation on the external corporate governance level, where recent developments on the internal corporate governance level points towards greater responsibility towards societal and employee interests. Only time will tell whether this inclination towards a stakeholderorientation on the internal corporate governance level, will eventually translate into a similar orientation on the external corporate governance level.

\section{Conclusion}

The objective of this paper was to determine whether there is theoretical or practical support for a normative definition of corporate governance that defines corporate governance as 'the external and internal system by which corporations are controlled in order to ensure a balance between individual, corporate and social interests'. On the theoretical level it was found that shareholder models of corporate governance that attend only to the interests of shareholders and not to those of other stakeholders do not support this normative definition, while stakeholder models of corporate governance are more likely to support it. In the survey of corporate governance practices around the world it was found that the countries included in the survey were almost split in the middle with regard to shareholder and stakeholder-orientations. The normative definition of corporate governance that was assessed in this paper seems to be practised to some extent only in those countries that subscribe to a stakeholder orientation to corporate governance. What has also become clear in the analysis of corporate governance practices around the world is that there is no clear convergence in the direction of either a shareholder or a stakeholder-model of corporate governance. 


\section{References}

Bebchuk, L.A. \& Roe, M.J. (1999). 'A theory of path dependence in corporate ownership and governance'. Stanford Law Review, 52(1), 127-170.

Bedicks H. \& Arruda C.C. (2005). 'Business ethics and corporate governance in Latin-America'. Business \& Society, 44(2), 218-228.

Branson, D.M. (2001). 'The uncertain prospect of 'global' convergence in corporate governance'. Cornell International Law Journal, 34, 321-362.

Coffee, J.C. (1998). Inventing a corporate monitor for transitional economies: The uncertain lessons from the Czech and Polish experiences. In K.J. Hopt, et al. Comparative corporate governance: the state of the art and emerging research. New York: Oxford University Press: 67-138.

Coffee, J. C. (1999). 'The future as history: The prospects for global convergence in corporate governance and its implications'. Northwestern University Law Review, 93(3), 641-707.

Collier, J. \& Robberts, J. (2001). 'An ethic for corporate governance?' Business Ethics Quarterly, 11(1), 67 - 71.

Demise N. (2005). 'Business ethics and corporate governance in Japan'. Business \& Society, 44(2): 211-217.

Donaldson, T. \& Preston, L.E. (1995). 'The stakeholder theory of the corporation: Concepts, evidence and implications'. Academy of Management Review, 20(1), 65-91.

Evan, W. \& Freeman, R. (1993). A stakeholder theory of the modern corporation: Kantian capitalism. In, $\mathrm{T}$. Beauchamp \& N. Bowie (Eds.) Ethical theory and business ( $4^{\text {th }}$ edition). New Jersey: Prentice Hall.

Fallon, W. \& Treleaven, L. (2006). From protagonists to partners: Participative research in the corporate landscape. [Online] Available at:

http://www.education.up.ac.za/alarpm/PRP_pdf/ Fallon\&Treleaven.pdf. (Accessed 4 September 2006).

Garrett, A. D. (2004). 'Themes and variations: The convergence of corporate governance practices in major world markets'. Denver Journal of International Law and Policy, 32, 147-174.

Gedajlovic, E.R. \& Shapiro, D.M. (1998). 'Management and ownership effects: Evidence from five countries'. Strategic Management Journal, 19: 533-553.

Goodpaster, K.E. (1993). Business ethics and stakeholder analysis. In, T.I. White (Ed.) Business Ethics: A philosophical reader. New York: MacMillan.

Hansmann, H. \& Kraakman, R. (2001). 'The end of history for corporate law'. Georgetown Law Journal, 89(2): 439468.

IoD (2002) King Report on Corporate Governance for South Africa 2002, Johannesburg: Institute of Directors IoD.
Kimber D. \& Lipton P. (2005). 'Corporate governance and business ethics in the Asia-Pacific region'. Business \& Society, 44(2): 178-210.

La Porta R., Lopez-de-Silanes F. \& Shleifer A. (1999). 'Corporate ownership around the world'. The Journal of Finance, 54(2): 471-517.

La Porta R., Lopez-de-Silanes F., Shleifer A. \& Vishny R. (2000). 'Investor protection and corporate governance'. Journal of Financial Economics 58: 3-27.

Monks, R. A. G. \& Minow, N. (2004). Corporate governance ( $3^{\text {rd }}$ ed.). Malden, MA: Blackwell.

Nestor, S. \& Thompson, J. K. (2000). Corporate governance patterns in OECD economies: Is convergence under way? [Online]. Available at: http://www.oecd.org/dataoecd/7/10/1931460. pdf (Accessed 4 September 2006).

Reed, D. (2002). 'Corporate governance reforms in developing countries'. Journal of Business Ethics 37: 223-247.

Reinecke, M.P.A. (1996). Effective corporate governance: A South African perspective. Unpublished masters dissertation. Johannesburg: Rand Afrikaans University.

Romano, R. (1998). Empowering investors: A market approach to securities regulation. In, K.J. Hopt, et al. Comparative corporate governance: The state of the art and emerging research. New York: Oxford University Press: 143-217.

Rossouw G.J. \& Sison, A.J.G. (Eds.) (2006). Global perspectives on the ethics of corporate governance. New York: Palgrave MacMillan.

Rossouw, D., Van der Watt, A. \& Malan, D. (2002). 'Corporate governance in South Africa'. Journal of Business Ethics, 37: 289-302.

Rossouw, G.J. (2005). 'Business ethics and corporate governance in Africa'. Business \& Society, 44(1): 94-106.

Ryan L. (2005). 'Corporate governance and business ethics in North-America: The state of the art'. Business \& Society, 44(1): 40-73.

Shleifer, A. \& Vishny, R.W. (1997). 'A survey of corporate governance'. The Journal of Finance, 52(2), 737-783.

Smerden, R. (1998). A practical guide to corporate governance. London: Sweet \& Maxwell.

Wieland J. (2005). 'Corporate governance, value management, and standards: A European perspective'. Business \& Society, 44(1), 74-93.
Address correspondence to: Deon Rossouw

Department of Philosophy

University of Pretoria

Pretoria, South Africa, 0001

e-mail: deon.rossouw@up.ac.za 
Reproduced with permission of the copyright owner. Further reproduction prohibited without permission. 